\title{
Kajian Prospek Penanaman Komoditas Tebu Rakyat Di Kabupaten Kerinci
}

\author{
Arman Delis, Nurhayani \\ Fakultas Ekonomi dan Bisnis, Universitas Jambi, Indonesia \\ Email corresponding author:armandelis@unja.ac.id/nurhayani@unja.ac.id
}

\begin{abstract}
ABSTRAK
Penelitian ini bertujuan untuk menganalisis potensi pengembangan perkebunan tebu, prospek pengembangan prosesing komoditas tebu menjadi gula merah dan gula putih, kelayakan pengembangan industri pengolahan gula tebu, integrasi pola pengelolaan perkebunan dan industri gula tebu dan dampak pengembangan perkebun tebu rakyat dan industri pengolahan gula terhadap tingkat kesejahteraan petani. Penelitian ini dilakukan di Kecamatan Kayu Aro dan Kecamatan Siulak. Penelitian ini menggunakan data primer dan data sekunder. Hasil penelitian menunjukkan bahwa Luasan tanaman perkebunan menempati urutan kedua setelah areal TNKS. Kontribusinya mencapai lebih dari seperempat total output daerah atau Produk Domestik Regional Bruto, sentra produksi tebu mengindikasikan bahwa pengembangan perkebunan tebu merupakan salah satu komoditi yang paling tepat dijadikan sebagai alternativ sumber penghasilan petani secara rutin atau berkelanjutan, usaha tani tebu telah menghasilkan keuntungan bagi petani ketika memasuki tahun ketiga. Perolehan keuntungan sebesar angka tersebut dapat memberikan jaminan arus pendapatan rumah tangga secara kontinyu dan berdimensi jangka panjang bagi petani di Kabupaten Kerinci
\end{abstract}

Kata kunci: tebu, gula merah dan gula putih

\section{PENDAHULUAN}

Pembangunan ekonomi pada umumnya bertujuan untuk meningkatkan kesejahteraan dan kemakmuran rakyat banyak. Sebagai salah satu negara yang sedang berkembang Indonesia selalu berusaha meningkatkan taraf hidup rakyatnya dengan cara mengadakan pembangunan di segala bidang. Sebagai negara maritim dan agraris maka pembangunan ekonomi harus berbasis dan sesuai dengan kompetensi produk unggulan di setiap daerah terutama produk pertanian dalam arti luas (Nurhayani, 2015). Subsektor perkebunan merupakan salah satu subsektor yang mengalami pertumbuhan paling konsisten, baik ditinjau dari areal maupunproduksi. Pulau Sumatera termasuk wilayah yang memiliki potensi cukup besar bagi pengembangan komoditas perkebunan tebu. Sebagian besar wilayah Pulau Sumatrea dilalui pegunungan Bukit Barisan disertai keberadaan beberapa Gunung Berapi aktif yang menganugerahi Pulau tersebut areal perbukitan dan dataran tinggi yang sangat subur dan cocok untuk pengembangan berbagai komoditas pertanian tanaman bahan makanan dan perkebunan.

Pemerintah menargetkan swasembada gula pada tahun 2017. Tahap awal mencapai target tersebut adalah menetapkan 10 Provinsi sebagai basis tebu dan lokasi pabrik baru gula. 10 provinsi tersebut adalah Sulawesi Tenggara, Sulawesi Selatan, Gorontalo, Sulawesi Tengah, Papua, Maluku, Lampung, Sumatera Selatan, Nusa Tenggara Barat dan Provinsi Nangroe Acah Darussalam. Tiga dari target yang ditetapkan oleh pemerintah berada di Pulau Sumatera. Produksi gula tebu nasional pada tahun 2016 sebesar 2.20 juta ton dan mengalami peningkatan 2017 mencapai 2.50 juta ton. Bila dilihat kebutuhan gula nasional pada tahun 2017 mencapai 5.7 juta ton, turun 1.38 persen dari tahun sebelumnya. Jumlah tersebut terdiri dari gula industry sebesar 2.8 juta ton dan gula konsumsi rumah tanga 2.9 juta ton. Konsumsi gula tebu yang lebih tinggi dibandingkan dengan produksi nasional membuka kesempatan untuk daerah lain mengembangkan produksi tebu nasional. 
Salah satu wilayah yang potensial dijadikan sebagai alternatif pengembangan areal perkebunan tebu di Sumatera adalah Kabupaten Kerinci Provinsi Jambi. Seluruh wilayah Kabupaten ini berada di lintasan Bukit Barisan yang beriklim tropis dan berhawa sejuk dengan suhu rata-rata sekitar $22^{\circ} \mathrm{C}$. Keberadaaan Gunung Kerinci sebagai gunung berapi tertinggi di Indonesia yang mengeluarkan abu vulkanik secara periodik menganugerahi daerah ini lahan yang memiliki tingkat kesuburan sangat tinggi. Kabupaten Kerinci telah berperan penting sebagai sentra produksi berbagai komoditi tanaman bahan makanan dan perkebunan termasuk hortikultura. Komoditi yang dihasilkan dari Kabupaten Kerinci bahkan berperan sebagai pemasok kebutuhan masyarakat di Pulu Jawa seperti Jakarta, Bandung dan Bogor.

Komoditas perkebunan tebu adalah salah satu komoditi yang telah dibudidaya oleh petani di Kabupaten Kerinci. Pengembangan budidaya tanaman tebu di daerah ini telah dikenal sejak pemerintah VOC mengerahkan tenaga kerja dari Pulau Jawa untuk dipekerjakan di areal perkebunan teh Kayu Aro. Seiring dengan peningkatan jumlah penduduk dan pekerja, daya serap tenaga kerja di perkebunan teh semakin terbatas. Sebagian tenaga kerja kemudian melepaskan diri secara perlahan dari pekerja perkebunan teh milik pemerintah kolonialis Belanda dan beralih mengembangkan areal perkebunan tanaman tebu seperti yang telah mereka tekuni di Pulau Jawa. Kegiatan budi daya tanaman perkebunan tebu kemudian semakin berkembang ketika Indonesia melepaskan diri dari belenggu penjajahan. Hingga saat ini perkebunan tanaman tebu masih ditekuni secara turun temurun oleh sebagian masyarakat migran asal Pulau Jawa dan bahkan telah berkembang dikalangan masyarakat daerah setempat.

Beranjak dari keberhasilan proyek percontohan penggilingan tersebut di atas, pemerintah daerah berencana untuk mengembangkan areal perkebunan tebu rakyat dengan skala usaha yang lebih besar disertai peningkatan prosesingnya menjadi gula tebu (gula putih) yang melibatkan lebih banyak tenaga kerja skill dan buruh termasuk petani lokal yang sebelumnya menggeluti usaha tani kayu manis dan tanaman bahan makanan khususnya sayur-sayuran. Sehubungan dengan rencana tersebut dipandang perlu untuk melakukan kajian secara lebih mendalam mengenai prospek pengembangan perkebunan tebu rakyat dan peningkatan aktivitas industri pengolahan gula di Kabupaten Kerinci.

Secara sederhana usaha tani diartikan sebagai himpunan sumber-sumber alam di suatu tempat yang diperlukan untuk melakukan aktivitas produksi pertanian seperti fisik tanah dan air, perbaikan-perbaikan yang dilakukan di atas tanah (misal penyiangan dan pemupukan), dan bangunan-bangunan yang didirikan di atas tanah (Mosher, 1968). Aktivitas produksi pertanian mencakup bidang-bidang bercocok tanam (pertanian dalam arti sempit), perikanan, peternakan, perkebunan, kehutanan, pengelolaan dan pemasaran hasil bumi (pertanian dalam arti luas) (Tohir, 1965). Berdasarkan konsep tersebut, usaha tani tebu tidak hanya mencakup aktivitas bercocok tanam tebu dan produksi tebu, pengolahan tebu menjadi gula dan pemasaran gula, tetapi menyangkut aspek yang lebih luas yaitu sosial ekonomi atau taraf penghidupan petani tebu yang mempengaruhi kegiatan pertaniannya.

Tebu (Sacharum officanarum) merupakan bahan baku utama industri gula, sehingga peningkatan produksi gula terintegrasi langsung dengan pengembangan perkebunan tanaman tebu. Oleh sebab itu, pemahaman terhadap karakteristik komoditi dan produksi tebu terutama yang mempunyai implikasi ekonomi, sangat penting dalam usaha meningkatkan produktivitas dan produksi tebu.

Produksi secara singkat diartikan sebagai aktivitas ekonomi yang menghasilkan atau meningkatkan nilai tambah (added value). Penciptaan atau peningkatan nilai tambah dapat terjadi melalui suatu proses produksi yang mengkombinasikan berbagai jenis input primer (tanah dan sumber daya alam, tenaga kerja dan kapital) dan input antara (bahan mentah, bahan baku, dan bahan bakar) dengan teknologi tertentu untuk menghasilkan sejumlah output (barang 
dan jasa) baik berupa produk antara (intermediate product) maupun produk akhir (final product).

Teori produksi menguraikan proses produksi pada berbagai tingkatan kegiatan ekonomi tersebut. Suatu usaha atau perusahaan berupaya mengoptimalkan output yang dihasilkan dengan mengkombinasikan penggunaan berbagai jenis input yang ada. Secara lebih teknis, hal tersebut digambarkan sebagai fungsi produksi yang menunjukkan hubungan teknis antara kuantitas output yang dapat dihasilkan dengan kuantitas input yang digunakan dalam proses produksi tersebut (Henderson dan Quandt, 1980). Suatu proses produksi hanya akan menghasilkan output yang optimal bila seluruh input digunakan secara efisien. Efisiensi penggunaan input itu sendiri akan tercapai apabila setiap input dimanfaatkan sedemikian rupa sehingga penambahannya satu unit dapat menghasilkan tambahan output yang nilai nominalnya sama dengan harga input tersebut. Dengan kata lain, sewa tanah, upah tenaga kerja, bunga modal dan balas jasa atas skill manajerial dibayar sesuai dengan tingkat produktivitas atau kontribusinya masing-masing dalam proses produksi.

Suatu komoditi dapat berperan sebagai basis perekonomian suatu wilayah apabila memiliki beberapa keunggulan secara komparativ sehingga dapat diekspor ke wilayah lainnya sepertinya aktivitas perdagangan antar negara. Secara konseptual peran suatu komoditas sebagai basis perekonomian wilayah dijelaskan dalam teori basis ekspor. Menurut teori ini suatu sektor atau komoditi basis kinerjanya lebih ditentukan oleh kondisi ekonomi eksternal terhadap perekonomian lokal, sementara sektor non-basis kinerjanya lebih bergantung pada kondisi ekonomi internal daerah itu sendiri (Fujita at al 2001 dan McCann 2001). Suatu industri dikatakan sebagai industri basis ekspor (export-base) apabila sebagian besar outputnya dipasarkan ke wilayah atau negara lain. Pada sisi lain, aktivitas ekonomi non-basis hanya melayani konsumen lokal seperti perdagangan eceran, tempat rekreasi, jasa-jasa legal, real estate, pendidikan, dan kesehatan.

Pengembangan komoditas pertanian dan industri pengolahannya dilakukan dalam suatu sistem agribisnis atau agroindustri yang masing-masing sub-sistemnya terintegrasi antara satu dengan yang lainnya. Jadi, agroindustri sesungguhnya merupakan sistem yang berupaya untuk meningkatkan produktivitas, efisiensi dan nilai tambah sektor pertanian. Pelaksanaannya dilakukan melalui penerapan berbagai inovasi teknologi, sosial dan ekonomi. Agroindustri memanfaatkan hasil pertanian sebagai bahan baku, merancang dan menyediakan peralatan serta jasa untuk kegiatan tersebut.

Industri Pengolahan Hasil Pertanian (IPHP) dapat dibagi menjadi beberapa bagian yaitu: (1) IPHP Tanaman Pangan, termasuk di dalamnya adalah bahan pangan kaya karbohidrat, palawija dan tanaman hortikultura; (2) IPHP Tanaman Perkebunan, meliputi tebu, kopi, teh, karet, kelapa, kelapa sawit, tembakau, cengkeh, kakao, vanili, kayu manis dan lain-lain; (3) IPHP Tanaman Hasil Hutan, mencakup produk kayu olahan dan non kayu seperti damar, rotan, tengkawang dan hasil ikutan lainnya; (4) IPHP Perikanan, meliputi pengolahan dan penyimpanan ikan dan hasil laut segar, pengalengan dan pengolahan, serta hasil samping ikan dan laut; dan (5) IPHP Peternakan, mencakup pengolahan daging segar, susu, kulit, dan hasil samping lainnya.

Studi yang terkait dengan tebu dan pergulaan Indonesia sudah banyak dilakukan, mulai dari sisi usahatani, industri gula, prduksi gula tebu di perusahaan, dan perdagangan gula. Hermawan (2012) menjelaskan Penggunaan luas lahan tebu sebagai salah satu upaya untuk mencapai keberhasilan swasembada gula dipengaruhi oleh harga gula dan tebu dan harga padi. Namun demikian harga gula dan tebu belum menjadi insentif yang kuat bagi perluasan pengusahaan tanaman tebu. Tunjungsari (2014) menjelaskan bahwa luas lahan, tenaga kerja dan pupuk berpengaruh terhadap produksi tebu Di Jawa Tengah Menurut Apriawan (2015) 
Peningkatan faktor produksi luas panen akan meningkat produksi tebu di Distrik Bungamayang PT. Perkebunan Nusantara VII (Persero). Menurut Nur (2017) agroindustri gula merah tebu Bapak Sukat di Desa Suka Makmur Kecamatan Wih Pesam Kabupaten Bener Meriah menguntungkan, dengan total keuntungan dengan prospek yang cerah untuk dikembangkan.

\section{METODE}

Penelitian ini dilakukan di Kecamatan Kayu Aro dan Kecamatan Siulak. Sentra produksi tebu dan gula tebu di Kecamatan Kayu Aro berada di tiga desa yaitu Desa Sungai Asam, Desa Pematang Lingkung dan Desa Kampung Baru. Selain ketiga desa tersebut terdapat wilayah pengembangan perkebunan tebu yang relativ baru yaitu Kecamatan Gunung Tujuh dan Sungai Bermas Kecamatan Siulak yang memulai usaha tani tebu sejak tahun 2010. Penelitian ini menggunakan data primer dan data sekunder. Data primer berkenaan dengan informasi mengenai usaha tani perkebunan tebu mencakup luas areal, sewa lahan, upah pengolahan lahan, pola tanam, biaya pemupukan, biaya pemiliharaan tanaman, upah penebangan, jumlah produksi tebu, upah penggilingan, rendemen, jumlah produksi gula, wilayah pemasaran gula, volume penjualan dan tingkat harga jual gula, produktivitas dan pendapatan petani. Data tersebut diperoleh langsung dari pengamatan dan hasil wawancara terhadap petani di wilayah sentra produksi.

Data primer dikumpulkan secara langsung ke objek penelitian melalui survei lapangan. Penggalian informasi yang dibutuhkan dilakukan dengan wawancara langsung terhadap beberapa petani dan/atau pabrik penggilingan tebu. Sementara itu, data sekunder dikumpulkan dari beberapa publikasi seperti Kerinci Dalam Angka, Statistik Perkebunan Provinsi Jambi, seri pulikasi Produk Domestik Regional Bruto (PDRB) dan kompilasi data statistik lainnya yang bersumber dari Badan Perencanaan Pembangunan Daerah (Bappeda), Badan Pusat Statistik Kabupaten Kerinci dan Dinas Perkebunan Kerinci.

Data sekunder dianalisis secara deskriptif untuk menggambarkan perkembangan peran sub sektor perkebunan terhadap sektor pertanian, peran perkebunan tebu rakyat terhadap sub sektor perkebunan dan potensi pengembangan perkebunan tebu dalam perekonomian wilayah Kabupaten Kerinci. Peralatan analisis yang digunanan adalah laju pertumbuhan, kontribusi dan kuosien lokasi, masing-masing diformulasikan sebagai berikut:

$$
\begin{aligned}
& r_{Q}=\frac{Q_{t}^{i}-Q_{t-1}^{i}}{Q_{t}^{i}} \times 100 \\
& S_{i}=\frac{Q_{i}}{Q} \times 100 \\
& L Q=\frac{Q_{i}^{r} / Q^{r}}{Q_{i}^{n} / Q^{n}}
\end{aligned}
$$

Dimana: $\mathrm{Q}=$ total output $\mathrm{Q}_{\mathrm{i}}=$ Nilai output sektor atau komoditas ke-i, $\mathrm{Q}_{\mathrm{t}}^{\mathrm{i}}=$ Output sektor atau komoditas ke-i pada waktu $t, \mathrm{Q}_{\mathrm{t}-1}{ }^{\mathrm{i}}=$ Output sektor atau komoditas ke- $i$ pada waktu $t-1, \mathrm{Q}_{\mathrm{i}}{ }^{\mathrm{r}}=$ Output sektor atau komoditas ke- $i$ di wlayah $r, Q^{r}=$ Total output sektor atau komoditas di wlayah $\mathrm{r}, \mathrm{Q}_{\mathrm{i}}^{\mathrm{n}}=$ Output sektor atau komoditas ke- $i$ di wlayah atasnya, dan $\mathrm{Q}^{\mathrm{n}}=$ Total output sektor atau komoditas di wilayah atasnya.

Berdasarkan data primer hasil survei lapangan dilakukan analisis kelayakan usaha tani dalam pengembangan lahan perkebunan tebu. Peralatan analisis yang digunakan adalah Net Present Benefit (NPB) dan Bebefit Cost Ratio (BCR). Kriteria NPB diformulasikan sebagai berikut: 
$N P B=\frac{\sum_{1}^{n}\left(B_{j}-C_{j}\right.}{(1+i)^{n}}$

dimana: $\mathrm{i}=$ tingkat bunga, $\mathrm{n}=$ umur tanaman tebu dan $\mathrm{j}=1,2,3$....n. Sedangkan kriteria kedua diformulasikan sebagai berikut:

$B C R=B_{0}+\frac{B_{1}}{(1+i)}+\frac{B_{2}}{(1+i)^{2}}+\cdots+\frac{B_{n}}{(1+i)^{n}}$

Berdasarkan metode ini, pengembangan perkebunan tebu dianggap layak untu dilaksanakan apabila nilai BCR-nya $>1$ dan sebaliknya dikatakan tidak layak. Metode ini konsisten dengan metode NPB, artinya jika nilai BCR usaha tani tebu lebih besar dari 1, maka nilai NPB nya akan positif.

\section{HASIL DAN PEMBAHASAN}

Areal tanaman perkebunan tebu di Kabupaten Kerinci sebagian besar merupakan lahan perkebunan yang telah ditanami sejak puluhan tahun silam, namun tanaman tersebut masih produktif dan dapat mensuplai input bagi pabrik penggilingan tebu. Areal perkebunan tebu tersebut sebagian besar besar terdapat di Kecamatan Kayu Aro terutama di tiga desa yaitu Sungai Asam, Kampung Baru, dan Lindung Jaya. Total luas areal tanam perkebunan tebu di Kabupaten Kerinci pada tahun 2017 mencapai 1.860 Ha yang terdiri atas tanaman tebu belum menghasilkan seluas 195 Ha di Kecamatan Kayu Aro, tanaman tebu yang masih menghasilkan seluas 1.665 Ha masing-masing di Kecamatan Kayu Aro 1.437 Ha dan Kecamatan Gunung Kerinci 30 Ha, Kecamatan Air Hangat 10 Ha, Kecamatan Gunung Tujuh 8 Ha dan Kecamatan Siulak $180 \mathrm{Ha}$.

Bila dilihat dari luas area perkebunan Tebu di Kabupaten Kerinci dari tahun ketahun mengalami peningkatan, pada tahun 2015 jumlah keseluruhan area tanaman tebu di Kabupaten ini seluas $1.664 \mathrm{Ha}$, dengan luas Tanaman Menghasilkan sebesar 1.484 Ha, Tanaman belum menghasilkan $180 \mathrm{Ha}$, pada tahun 2016 terjadi peningkatan luas area perkebunan tebu menjadi $1.838 \mathrm{Ha}$, yang diikuti dengan peningkatan tanaman yang mengasilkan seluas $1.668 \mathrm{Ha}$, dan penurunan padan tanaman yang belum menghasilkan menjadi $170 \mathrm{Ha}$. Bila dilihat dari jumlah Produksi dan jumlah petani tebu selama 3 tahun mengalami fluktuasi. Pada tahun 2015 jumlah produksi tebu sebesar 7.374 Ton dengan jumlah petani sebanyak 1.487 orang, pada tahun 2015 jumlah produksi tebu mengalami peningkatan, dengan total produksi sebesar 15.283 ton dan jumlah petani sebanyak 1.462 orang, sedangkan untuk tahun 2017 jumlah mengalami penurunan menjadi 9.655 ton dan jumlah petani mengalami peningkatan sebesar 1.554 orang. Penurunan jumlah produksi disebabkan adanya peningkatan tanaman tebu yang belum menghasilkan dari 170 Ha tahun 2016 menjadi 195 Ha tahun 2017 sehingga mengurangi jumlah produksi tebu yang dihasilkan. 
Tabel 1. Luas Areal Tanaman Tebu Tahun 2017

\begin{tabular}{|c|c|c|c|c|c|c|c|c|}
\hline \multirow[b]{2}{*}{ No. } & \multirow[b]{2}{*}{ (district) } & \multicolumn{4}{|c|}{ LUAS AREAL/ Area (Ha) } & \multirow{2}{*}{$\begin{array}{l}\text { Production } \\
\text { Kg/Ha }\end{array}$} & \multirow{2}{*}{$\begin{array}{l}\text { Productivity } \\
\text { (Kg/Ha) }\end{array}$} & \multirow[b]{2}{*}{ Farmers (KK) } \\
\hline & & TBM/ & $\mathbf{T M}$ & TTM/TR & Total & & & \\
\hline 1 & Gunung Kerinci & - & 30 & - & 30 & 150 & - & 8 \\
\hline 2 & Kayu Aro & - & 1,437 & - & 1,437 & 8,622 & 6,000 & 1,345 \\
\hline 3 & Air Hangat & - & 10 & - & 10 & 45 & - & - \\
\hline 4 & Gunung Tujuh & - & 8 & - & 8 & 40 & 5,000 & 9 \\
\hline 5 & Siulak & 195 & 180 & - & 375 & 792 & 4,400 & 182 \\
\hline 6 & Depati VII & - & - & - & - & - & - & - \\
\hline
\end{tabular}

Sumber: Dinas Perkebunan, 2017

$$
\begin{aligned}
\text { Catatan }: \text { TBM } & =\text { Tanaman Belum Menghasilkan } \\
\text { TM } & =\text { Tanaman Menghasilkan } \\
\text { TTM } & =\text { Tanaman Tidak Menghasilkan }
\end{aligned}
$$

Prospek pengembangan areal tanaman perkebunan tebu secara mikro dapat dilihat dari kelayakan ekonomi usaha taninya dan jaminan pemasaran produk yang dihasilkan. Usaha tani tebu di Kabupaten Kerinci dilakukan diareal perbukitan, berbeda dengan perkebunan tebu di Pulau Jawa yang dilakukan di areal persawahan. Pengembangan areal perkebunan tebu tidak menyebabkan berkurangnya areal lahan persawahan yang sangat diperlukan untuk menjaga stabilitas produksi padi dan beras. Kompetisi dan substitusi penggunaan lahan untuk tanaman perkebunan tebu hanya terjadi antar komoditas perkebunan lainnya, bukan tanaman padi dan bahan maknan lainnya. Pengembangan areal perkebunan tebu dapat dilakukan dengan memanfaatkan lahan tidur dan areal lahan perkebunan tanaman lainnya yang sudah berusia tua dan tidak menghasilkan lagi. Pada tahun 2017 tidak lagi ditemukan lahan perkebunan yang sudah berusia tua atau rusak mencapai. Hasil survei yang dilakukan ke sentra produksi tebu mengindikasikan bahwa pengembangan perkebunan tebu merupakan salah satu komoditi yang paling tepat dijadikan sebagai alternativ sumber penghasilan petani secara rutin atau berkelanjutan. Komoditi ini juga memiliki prospek yang sangat baik bila dilihat dari kontnyuitas permintaan pasarnya. Sebagai komoditi yang berperan memasok kebutuhan bahan baku industri pengolahan pangan, permintaannya relativ lebih stabil bila dibandingakan dengan komoditas tanaman perkebunan lainnya, apalagi bila dibandingkan dengan komoditi sayursayuran seperti kentang, tomat, kol, dan cabe merah.

Survei yang dilakukan di sentra produksi perkebunan tebu yang telah berusia cukup lama yaitu Desa Sungai Asam menghasilkan beberapa informasi yang cukup menarik. Berdasarkan wawancara yang dilakukan dengan Ketua Kelompok Tani Sidoarjo Desa Sungai Asam diketahui bahwa setiap kelompok tani beranggota sekitar 20 orang. Secara rata-rata, setiap petani memiliki 1-2 hektar lahan perkebunan tebu dengan total luas lahan mencapai 30 hektar. Secara rata-rata setiap petani melakukan panen tiga kali dalam satu minggu. Sesuai dengan kapasitas mesin, penggilingan dapat dilakukan 6 kali sehari sehingga dalam satu minggu dapat 
dilakukan 42 kali penggilingan atau secara rata-rata setiap petani memiliki kesempatan melakukan penggilingan sebanyak 1-3 kali seminggu. Dengan luas lahan 1-2 hektar, seorang petani dapat melakukan penggilingan hingga 4 kali dalam satu minggu. Volume satu kali penggilingan berkisar sekitar $700 \mathrm{~kg}$ tebu yang menghasilkan sekitar $80 \mathrm{~kg}$ bersih gula tebu merah. Ini berarti rendemen tebu rakyat di Kabupaten Kerinci mencapai 11 persen, jauh lebih tinggi dari rendemen tebu unggul di Pulau Jawa yang hanya sebesar 7,5 persen. Dengan frekuensi penggilingan sebanyak 4 kali per minggu berarti seorang petani dapat menghasilkan gula merah sebanyak $320 \mathrm{~kg}$ per minggu. Apabila dikalikan dengan harga gula sekitar Rp 9.000 per kg, perolehan kotor petani mencapai Rp 2.880.000 per minggu atau Rp. 11.520.000. per bulan.

Pengoperasian mesin penggilingan dilakukan oleh seorang tenaga operator dengan upah Rp 60.000 per kali giling. Apabila dikalikan dengan frekuensi penggilingan sebanyak 4 kali giling per minggu diperoleh upah operator per minggu sebesar Rp 240.000 atau Rp 960.000 per bulan. Pemakaian mesin penggilingan bantuan pemerintah oleh setiap anggota kelompok tani dikenakan biaya sewa sebesar Rp 10.000 setiap kali penggilingan. Total biaya penggilingan selama satu minggu adalah Rp 40.000 atau Rp 160.000 per bulan. Bahan bakar minyak solar yang digunakan untuk mengoperasikan mesin berjumlah 2 liter dengan nilai sekitar Rp 11.000 per kali giling. Jadi biaya bahan bakar selama satu minggu adalah Rp 44.000 atau satu bulan sebesar Rp176,000. Biaya lainnya yang dikeluarkan untuk mengoperasikan mesin adalah pembelian gumuk sebesar Rp 14.000 per kali giling atau Rp 224.000 per bulan. Jumlah keseluruhan biaya pengolahan tebu atau produksi gula adalah sebesar Rp. 1.360.000.

Tabel 2. Analisis Usaha Tani Tebu Rakyat di Kabupaten Kerinci

\begin{tabular}{rlr}
\hline No. & Uraian & Nilai (Rp) \\
\hline 1 & Sewa lahan & 350.000 \\
2 & Upah Penyiangan & 820.000 \\
3 & Upah Penebangan & 1.200 .000 \\
4 & Upah Operator & 960.000 \\
5 & Sewa Penggilingan & 160.000 \\
6 & Bahan Bakar & 176.000 \\
7 & Gumuk & 224.000 \\
Total Biaya (TC) & 3.890 .000 \\
Penerimaan (TR) & 11.520 .000 \\
Keuntungan & 7.630 .000 \\
Persentase Keuntungan & 0,66 \\
Rasio Keuntungan-Biaya & 1,96 \\
\hline
\end{tabular}

Sumber : Hasil Survei Lapangan, 2017

Rasio antara total penerimaan dengan total biaya adalah sebesar 2,96, sementara rasio keuntungan (di luar komponen sewa lahan) terhadap biaya adalah sebesar 2,15. Artinya total penerimaan mencapai lebih dua kali lipat dari total biaya, sementara keuntungan hampir mencapai dua kali lipat biaya. Analisis usaha tani tersebut dapat dirangkum dalam tabel 5.1

Hasil analisis terhadap usaha tani perkebunan tebu rakyat yang telah berproduksi memperlihatkan bahwa usaha tani tebu dapat memberikan sumber penghasilan yang cukup memadai bagi petani bila dibandingkan dengan usaha tani lainnya seperti perkebunan kayu 
manis yang telah dibudidaya selama bertahun-tahun atau usaha tani tanaman bahan makanan seperti kentang, cabe merah dan kubis yang tingkat harganya sangat berfluktuasi. Faktor kreatifitas merupakan factor penting bagi keberhasilan usaha, sehingga pengusaha dapat lebih serius dalam beriwirausaha dan mencoba menjadi lebih kreatif dalam memanfaatkan peluang yang timbul (Ekasari, 2018). Berdasarkan hasil analisis tersebut perluasan areal tanaman perkebunan tebu dengan memanfaatkan lahan tidur dan lahan eks perkebunan tua atau peralihan penggunaan lahan dari berbagai jenis tanaman perkebunan kurang produktiv atau tingkat keuntungannya rendah seperti tanaman perkebunan kayu manis ke tanaman perkebunan tebu sangat layak dilakukan.

Tabel 3. Analisis Pengembangan Lahan Usaha Tani Tebu Rakyat Di Kabupaten Kerinci

\begin{tabular}{lrrr}
\hline \multicolumn{1}{c}{ Komponen Biaya } & Tahun ke-1 & Tahun ke-2 & Tahun ke-3 \\
\hline Pembelian Lahan 1 Hektar & 35.000 .000 & - & - \\
Upah Perambahan & 2.640 .000 & - & - \\
Upah Pengolahan Lahan & 6.600 .000 & - & - \\
Pembelian Bibit & 5.250 .000 & - & - \\
Pembelian Pupuk Kandang & 200.000 & - & - \\
Upah Penyiangan & 11.880 .000 & 9.900 .000 & 11.880 .000 \\
Upah Penebangan & - & 7.200 .000 & 17.280 .000 \\
Upah Operator & - & 3.840 .000 & 8.640 .000 \\
Sewa Mesin Penggiling & - & 768.000 & 1.728 .000 \\
Biaya Bahan Bakar & - & 1.152 .000 & 2.304 .000 \\
Biaya Gumuk & - & 960.000 & 2.304 .000 \\
Total Biaya & 61.570 .000 & 13.920 .000 & 32.256 .000 \\
Penerimaan & - & 73.760 .000 & 122.880 .000 \\
Keuntungan & - & $(6.730 .000)$ & 8894.000 \\
Persentase Keuntungan & - & - & 72,34 \\
Rasio Keuntungan-Biaya & - & - & 2,76 \\
\hline Hasi Survi Lapangan
\end{tabular}

Hasil Survei Lapangan

Hasil perhitungan secara kasar seperti yang dilakukan di atas menunjukkan bahwa usaha tani tebu telah menghasilkan keuntungan bagi petani ketika memasuki tahun ketiga. Perolehan keuntungan sebesar angka tersebut dapat memberikan jaminan arus pendapatan rumah tangga secara kontinyu dan berdimensi jangka panjang bagi petani di Kabupaten Kerinci. Kesimpulannya adalah pengembangan lahan tanaman tebu rakyat sangat prospektif secara ekonomi dan sangat layak menjadi alternativ terhadap kesulitan yang dihadapi masyarakat dalam menjalani usaha tani perkebunan kayu manis dan tanaman bahan makanan.

Analisis usaha tani tanaman perkebunan tebu yang telah ada di Kayu Aro dan Bermas dan analisis investasi pengembangan lahan tanaman tebu di areal yang baru, masih terbatas dalam produksi gula merah seperti yang telah dilakukan petani sampai saat ini. Produksi gula merah masih dapat dilakukan dengan menggunakan penggilingan tradisional dan mesin penggilingan sederhana. Bahan baku industri gula merah atau gula petak dapat dipasok dari tanaman tebu rakyat yang dikembangkan dari bibit tebu lokal. Apakah potensi lahan perkebunan, skill petani tebu dan peluang pasar domestik yang besar dapat dimanfaatkan dengan meningkatkan prosesing tebu menjadi gula putih?. Berikut ini akan dilakukan kajian 
pendahuluan kemungkinan pengembangan industri gula putih berskala mini di Kabupaten Kerinci.

Pembangunan pabrik gula mini berkapasitas 30 tcd membutuhan investasi awal (termasuk lahan) Rp 4.480.000 (Lampiran 1). Dana sejumlah tersebut lebih mudah disediakan pemerintah daerah dalam bentuk pendirian Badan Usaha Milik Daerah (BUMD) dengan manjemen swasta murni. Alternativ lain disediakan oleh investor swasta sebagai pabrik milik pengusaha swasta. Sebaliknya tidak mudah memobilisasi dana untuk investasi awal dari pihak petani, kecuali aset tetap yang dimiliki berupa tanah. Pernan Pemerintah sebagai pembuat kebijakan dapat dilaukan dengan memberikan bantuan kepada para petani melalui pemberian bantuan modal, bibit tebu, penyuluhan oleh instansi terkait serta penyediaan infrastruktur untuk membantu kelancaran proses produksi dan distribusi. Membangun infrastruktur yang baik terutama di daerah - daerah akan mempercepat mobilitas perekonomian wialayh tersebut (Rosmeli, 2014).

Analisis usaha tani tebu bibit unggul tidak jauh berbeda dengan usaha tani tebu bibit unggul seperti yang telah dilakukan sebelumnya. Perbedaan utamanya terletak pada biaya pembelian bibit, pupuk dan biaya pengolahan tebu. Apabila petani hanya berperan sebagai pemasok bahan baku ke pabrik gula, maka biaya yang dikeluarkan hanya sebatas pemiliharaan atau penebangan. Selebihnya merupakan proses pengolahan tebu menjadi gula yang sepenuhnya merupakan beban biaya produksi yang ditanggung oleh perusahaan. Pemasaran tebu dapat dilakukan melalui promosi oleh petani maupun perusahaan, baik secara online atau dengan jalur distribusi pemasaran, hal ini sejalan dengan penelitian yang dilakukan oleh Ekasari (2014) yang menyatakan bahwa dengan promosi pemasaran diharapkan produk yang dihasilkan akan dikenal oleh masyarakat luas.

\section{KESIMPULAN DAN SARAN}

Komoditi-komoditi tanaman perkebunan memberikan peran bagi kehidupan masyarakat Kerinci selama beberapa dekade hingga 1980-an. Luasan tanaman perkebunan menempati urutan kedua setelah areal TNKS. Kontribusinya mencapai lebih dari seperempat total output daerah atau Produk Domestik Regional Bruto pada tahun 2010, namun produktivitas sebagian besar komoditas perkebunan tersebut relativ rendah dan bagian harga yang diterima petani relativ kecil sehingga tingkat kesejahterann petani relativ rendah. Proporsi areal komoditas tanaman tebu terhadap total areal tanaman perkebunan, relativ sangat kecil, namun proporsinya terhadap total output perkebunan relativ lebih besar Angka-angka ini mengindikasikan bahwa penghidupan petani tebu relativ lebih baik dari tanaman perkebunan lainnya. Komoditas tebu rakyat memiliki keunggulan komparativ untuk dikembangkan sebagai basis ekspor ke daerah lain di sekitar Kabupaten Kerinci sekaligus dapat mendorong pertumbuhan ekonomi daerah dan meningkatkan pendapatan petani. Pemberian bantuan mesin pengolahan tebu oleh pemerintah telah meningkatkan produktivitas gula tebu dan meningkatkan pendapatan petani sehingga meningkatkan minat petani menanam komoditas tebu. Analisis usaha tani untuk tanaman perkebunan tebu yang telah berusia cukup tua menunjukkan bahwa aktivitas produksi tebu dan gula mampu menghasilkan keuntungan sehingga komoditas ini dapat menjadi sumber penghidupan masyarakat. Analisis kelayakan investasi pengembangan lahan perkebunan tebu menunjukkan bahwa tingkat pengembalian investasi relativ cepat dimana investasi awal hampir tertutupi padatahun kedua dan keuntungan mencapai lebih dua pertiga dari penerimaan. Pengembangan industri pengolahan gula tebu putih di Kabupaten Kerinci sangat memungkinkan bila dilihat dari ketersediaan lahan, ketrampilan petani dalam mengelola perkebunan tebu, keahlian dalam memproses pembuatan gula merah. 
Lebih lanjut, untuk mengembangkan usaha tebu perlu dukungan dari keseluruhan elemen, tidak hanya dari sisi internal pelaku petani saja tetapi juga diperlukan peran pemerintah dalam mendukung pengembangan usaha, seperti dengan memberikan pendidikan dan pelatihan kepada pelaku petani melalui bimbingan dan penyuluhan untuk meningkatkan kemampuan petani dan memberikan bantuan modal dalam pengolahan tanaman tebu.

\section{DAFTAR PUSTAKA}

Apriawan,D, C, Irham, Mulyo, J, H, (2015). Analisis Produksi Tebu Dan Gula Di Pt. Perkebunan Nusantara Vii (Persero). Agro Ekonomi Vol. 26/No. 2, Desember, Hal 159 $-167$.

A.T. Mosher. 1966. Mengerakkan dan Membangun Pertanian, terjemahan Ir.Krisnandhi CV. Yasa Guna, Jakarta,

Departemen Pertanian, 2005. Balai Besar Penelitian dan Pengembangan Sumberdaya Lahan Pertanian. Badan Penelitian dan Pengembangan Pertanian. Balai Penelitian Tanah. Departemen Pertanian Jakarta.

Ekasari Novita (2014). Pengaruh Promosi berbasis sosial media terhadap keputusan pembelian produk jasa pembiayaan kendaraan pada PT. BFI Finance Jambi. Jurnal penelitian universitas Jambi: Seri Humaniora 16 (2).

dan Nurhasanah (2018). Pengaruh Lokasi dan Kreatifitas Terhadap keberhasilan usaha Mikro Kecil Menengah (UMKM) di Kawasan wisata Gentala Arasy Kota Jambi. Jurnal Sains Sosiohumaniora 2 (1), 1 - 15

Hermawan, I. (2012). Analisis Penggunaan Luas Lahan Tebu Dan Padi Terkait Dengan Pencapaian Swasembada Gula Di Indonesia. Jurnal Ekonomi \& Kebijakan Publik, Vol. 3 No. 1, Juni. hal $47-63$.

Kaslan A. Tohir. 1965. Pengentar Ekonomi Pertanian, Sumur Bandung

Mubyarto. 1987. Pengantar Ekonomi Pertanian. LP3ES Jakarta

Mccann, P, 2001. "Urban and Regional Economic”. Oxford University Press, New York.

Nur, E, T, M. ( 2017). Rospek Pengembangan Usaha Pengolahan Gula Merah Tebu Di Desa Suka Makmur Kecamatan Wih Pesam Kabupaten Bener Meriah (Studi Kasus Agroindustri Bapak Sukat Suwarto). Jurnal S. Pertanian 1 (11), Hal 929 - 937.

Nurhayani. (2015). Analisis peranan sub sektor tanaman pangan dalam pembangunan. Jurnal Paradigma Ekonomika, Vol 10. No 2. 270 -290.

Rosmeli, 2014. “ Dampak Belanja Daerah Terhadap Ketimpangan Antar Daerah di Provinsi Jambi”. Jurnal Paradigma Ekonomi, Volume 9 No 01 April 2014. Hal 85 - 92

Sugandi, K,W, Suastawa, N, I, Wiyino, J. (2017). Kondisi Lahan Kebun Tebu Setelah Panen Dan Karakteristikfisik Dan Mekanik Serasah Tebunya. Jurnal Teknik Pertanian Lampung Vol.6, No. 3: 133-140. Hal. 133-140.

Tunjungsari, R. (2014). Analisis Produksi Tebu Di Jawa Tengah. Jejak Journal Of Economics And Policy 7 (2). Hal $121-133$. 